\title{
Wage inequality in the Netherlands: Evidence, trends and explanations
}

Stefan Groot

Henri de Groot 



\title{
Wage inequality in the Netherlands:
}

\section{Evidence, trends and explanations}

\author{
Stefan P.T. Groot and Henri L.F. de Groot ${ }^{1}$
}

\begin{abstract}
For many years, the Netherlands has been considered an exception to the general trend of growing wage inequality that most OECD countries have experienced since the 1980s. This OECD trend is generally explained by increasing relative demand for skilled labour due to skill biased technological progress and to a lesser extent - by globalization. Using detailed micro data on the entire wage distribution in the Netherlands, this paper examines trends in Dutch (real pre-tax) wage inequality between 2000 and 2008. We show that the aggregate flatness of the distribution hides dynamics between different groups and regions. We find that inequality, after correcting for observed worker characteristics, decreased somewhat at the lower half of the wage distribution, while increasing slightly at most of the upper half (both before and after correcting for differences in human capital). Residual wage inequality is high and increasing in most larger cities, which is in line with recent evidence on the increasing importance of agglomeration externalities.
\end{abstract}

JEL codes: D31, E24, J31, O15, R23

Keywords: income distribution, labour market composition, human capital, wage structure

\footnotetext{
${ }^{1}$ Henri de Groot would like to dedicate this paper to Richard Nahuis who so sadly and unexpectedly passed away in 2005. Parts of this paper build on Nahuis and De Groot (2003). Furthermore, this paper partly builds on the CPB publication 'India and the Dutch economy' (Suyker et al., 2007). We acknowledge the assistance of Statistics Netherlands for making the data available. We are grateful to Nicole Bosch, Harry Garretsen, Peter Mulder and Bas ter Weel for useful comments on an earlier version of this paper, and to various participants for their inputs during the Eureka Lunch Seminar at the VU University. The usual disclaimer applies.
} 


\section{Introduction}

Rising wage inequality in the United States and other OECD countries has provoked debates on the severity of this phenomenon, its causes, and its potential remedies. Up to now, however, the size of changes in the income distribution and especially its causes, have remained controversial issues. During the 1980s and 1990s, wages of some groups on the U.S. labour market - especially blue collar workers - have fallen in real terms, whereas the wages of workers in the higher percentiles of the wage distribution have grown substantially (Lawrence, 2008). The Netherlands is often considered an exception to this general picture. Changes in wage inequality have been mild, both when compared to the substantial increase in U.S. wage inequality and when compared to trends in most other European countries. For The Netherlands, Ter Weel (2003) shows that the $90-10^{\text {th }}$ percentile wage differential increased by less than two percent between 1992 and 1998, after having increased by eight percent between 1986 and 1992. Similarly, Atkinson and Salverda (2005) have shown that Dutch inequality has remained fairly stable during most of the 1977-1999 period.

The literature on Dutch wage inequality in recent years is limited, despite several important trends such as globalization and the advent of ICT that may have impacted the wage distribution, especially in the past decade. This paper describes and explains trends in the Dutch wage distribution during the 2000-2008 period, using detailed micro data on wages and employee characteristics. We show that the best-paid workers have gained more during this period than workers in the middle of the distribution. Workers at the lower percentiles, however, have gained as well relative to the median worker. The $99-90^{\text {th }}$ wage differential has increased by 1.3 percent, and the $90-50^{\text {th }}$ differential by 0.2 percent. At the bottom end of the wage distribution, inequality has fallen, as the $50-10^{\text {th }}$ differential decreased by 2.0 percent. The net effect of these changes on aggregate inequality measures such as the Theil and Gini coefficients boils down to only a very moderate increase in inequality.

An important advantage of using micro data instead of macro data is that the former can provide insights in how changes observed in the aggregate wage distribution are related to changes in (implicit) prices and volumes of individual worker characteristics. This allows us to show that changes in aggregate wage inequality have no single explanation, but are the net effect of diverse and complex interactions on the labour market. More specifically, we will describe levels and trends of Dutch wage inequality, and apply the framework of Juhn et al. (1993) to 
distinguish three types of effects: (i) quantity changes of observable worker characteristics - e.g. the effect of changes in labour market composition; (ii) changes in the implicit prices of worker characteristics; and (iii) residual changes that are related to unobservable worker characteristics. Additionally, we use this method to identify trends in prices and quantities of isolated components of human capital, like education and age. Well-paid jobs are not uniformly distributed across professions and regions. We will therefore present our results not only for the economy as a whole, but also for different regions. This shows that after correcting for observed human capital, wages in the four largest agglomerations of the Netherlands (Amsterdam, Rotterdam, The Hague and Utrecht) pay a premium of 8.9 (8.3) percent in 2008 (2000).

Skill-biased technological progress is generally considered the most plausible explanation for increasing wage inequality in the U.S. (Katz and Murphy, 1992; Autor et al., 1998 and 2006). Other potential causes are globalization, reduced supply of skilled labour, and labour market institutions (see, for example, Nahuis and De Groot, 2003). The theories result in very similar testable hypotheses: rising skill and experience premiums. The mechanisms through which they operate are, however, very different. In the first case, technological progress increases relative demand for skills. For example, the advent of information and communication technology might be in favour of especially the high-skilled (Katz and Murphy, 1992; Autor et al., 1998 and 2006). In the case of globalization it is increased competition with countries housing large pools of unskilled workers that reduces the relative demand for low-skilled and thus increases the skill premium. The third case emphasises the fact that access to higher education is no longer increasing as it did during the 1970s and 1980s reducing the (growth of) the supply of high skilled (or alternatively that the quality of high skilled is deteriorating). It has proven difficult to empirically separate these different forces, and the debate is far from settled. Ter Weel (2003) and Nahuis and De Groot (2003) argue that the relative stability of the Dutch wage distribution is explained by the fact that educational attainment has continued to grow for a relatively long period in time. Increased demand for skilled labour (possibly caused by skill biased technological progress or globalization) was thus balanced by increased supply of skilled workers, such that the resulting price of skills showed little change. In countries where supply of skilled labour remained constant, it resulted in a higher skill premium and thereby higher wage inequality. Nowadays, the number of highly educated workers is increasing at a much lower rate. Reduced supply of skilled labour is likely to increase the skill premium and, again, to raise inequality. In 
the Netherlands, the skill premium has increased by 12.3 percent between 2000 and 2008, which suggests that the market for skills has tightened. Finally, the effects of labour market institutions on the wage distribution can be substantial (Alderson and Nielsen, 2002; De Groot et al., 2006a and 2006b, Gottschalk and Smeeding, 1997). Changes in the way wages are negotiated, minimum wages, unemployment benefits, unionisation, and other institutions are known to be important determinants of wage inequality (Teulings and Hartog, 1998).

The remainder of this paper is organized as follows. The next section will present the micro data used in this paper. Section 3 presents descriptive statistics on (trends in) Dutch wage inequality between 2000 and 2008. Section 4 discusses the methodology that we have used to decompose trends in inequality in different components, and present the results of this exercise. Section 5 focuses on the regional dimension of wage inequality. And Section 6 concludes.

\section{Data}

We use employee micro data from Statistics Netherlands (CBS). Data on worker characteristics are drawn from nine consecutive cross-sections of the annual labour market survey (EBB, Enquête Beroepsbevolking) covering the period 2000-2008. ${ }^{2}$ For wages, we rely on tax data reported by employers, available through the CBS social statistics database (SSB, Sociaal Statistisch Bestand). For workers with multiple jobs, we include each job as a separate observation. We have used the CBS consumer prices deflator (CPI, Consumenten Prijs Index) to deflate annual earnings. Throughout most of our analyses, we rely on log hourly wages, defined as the natural logarithm of the deflated pre-tax wage divided by the number of hours worked.

To make sure that only workers with a sufficiently strong attachment to the labour market are included, we have imposed the following restrictions. First, workers must be aged 18-65, and must work for at least 12 hours per week. ${ }^{3}$ Second, the hourly wage should exceed the minimum wage in 2008 (adjusted for inflation). Third, wages should not exceed 10 times the median wage to avoid an excess impact of extremely high incomes. We use age as a proxy for experience, which captures different sources of human capital, including - but not limited to - present and

\footnotetext{
${ }^{2}$ Due to methodological changes in the labour market survey, there is a discontinuity in our dataset between 2005 and 2008. The effects of this change have been filtered out keeping the wage distribution constant between 2005 and 2006.

${ }^{3}$ Statistics Netherlands defines workers with a working week of at least 12 hours as employed, workers with a working week of at least 36 hours are considered full-time employees. Jobs occupied by teenagers are often sideline jobs, that would be outliers in our dataset.
} 
previous occupations. We measure education as the nominal number of years of schooling that is needed to achieve the highest level of education that a worker has successfully achieved. Other worker characteristics that are included are country of birth (a binary variable that indicates whether a worker is born in the Netherlands or not), gender, and whether a worker is employed part-time or full-time. The resulting dataset of nine cross-sections contains 436,734 observations, an average of 48,526 per year.

Table 1 presents some descriptive statistics on the key variables of interest. It must be kept in mind that all figures reflect our sample rather than the total Dutch working population, and thus may not be fully representative. Pre-tax real wages have increased by 6.3 percent between 2000 and 2008. Even though the period of observation is limited, some pronounced changes have occurred. Workers in 2008 have experienced on average 0.51 years more education than workers in 2000, and are 1.91 years older. The share of women has increased by 6.3 percentage points, while the share of part-time jobs increased by 1.3 percentage points. As parttime workers and females tend to be overrepresented at the lower percentiles of the wage distribution, and older and higher-educated workers feature most prominently at the higher percentiles, this could have resulted in increasing wage inequality. If, however, changes in worker characteristics are evenly distributed (if the higher average age is, for example, not the result of increased labour market participation of older workers, but only a level effect), inequality would have remained unchanged. The use of micro data gives the possibility to determine what driving forces are dominant, and how they interact. 
Table 1. Descriptive statistics, 2000-2008

\begin{tabular}{|c|c|c|c|c|c|}
\hline & 2000 & 2002 & 2004 & 2006 & 2008 \\
\hline \# Observations & 17,829 & 22,953 & 45,553 & 82,676 & 82,089 \\
\hline Log real hourly wage & $\begin{array}{c}2.913 \\
(0.424)\end{array}$ & $\begin{array}{c}2.939 \\
(0.422)\end{array}$ & $\begin{array}{c}2.955 \\
(0.426)\end{array}$ & $\begin{array}{c}2.955 \\
(0.425)\end{array}$ & $\begin{array}{c}2.976 \\
(0.426)\end{array}$ \\
\hline Age & $\begin{array}{c}40.67 \\
(10.48)\end{array}$ & $\begin{array}{c}41.12 \\
(10.64)\end{array}$ & $\begin{array}{c}41.78 \\
(10.75)\end{array}$ & $\begin{array}{c}42.19 \\
(10.68)\end{array}$ & $\begin{array}{c}42.58 \\
(11.00)\end{array}$ \\
\hline Education (years) & $\begin{array}{c}14.39 \\
(3.162)\end{array}$ & $\begin{array}{c}14.45 \\
(3.148)\end{array}$ & $\begin{array}{c}14.71 \\
(3.129)\end{array}$ & $\begin{array}{c}14.83 \\
(3.119)\end{array}$ & $\begin{array}{c}14.90 \\
(3.116)\end{array}$ \\
\hline Females & $\begin{array}{c}0.368 \\
(0.489)\end{array}$ & $\begin{array}{c}0.397 \\
(0.492)\end{array}$ & $\begin{array}{c}0.415 \\
(0.493)\end{array}$ & $\begin{array}{c}0.420 \\
(0.494)\end{array}$ & $\begin{array}{c}0.431 \\
(0.495)\end{array}$ \\
\hline Part-time & $\begin{array}{c}0.506 \\
(0.483)\end{array}$ & $\begin{array}{c}0.531 \\
(0.487)\end{array}$ & $\begin{array}{c}0.567 \\
(0.492)\end{array}$ & $\begin{array}{c}0.582 \\
(0.493)\end{array}$ & $\begin{array}{c}0.566 \\
(0.496)\end{array}$ \\
\hline Foreign born & $\begin{array}{c}0.072 \\
(0.258) \\
\end{array}$ & $\begin{array}{c}0.075 \\
(0.264) \\
\end{array}$ & $\begin{array}{c}0.071 \\
(0.258) \\
\end{array}$ & $\begin{array}{c}0.074 \\
(0.262) \\
\end{array}$ & $\begin{array}{c}0.080 \\
(0.271) \\
\end{array}$ \\
\hline
\end{tabular}

Note: standard deviations are between parentheses.

\section{Trends in inequality}

Before we start exploring the determinants of both levels and trends in the distribution of wages, we first look in somewhat greater detail at the dynamics of wage inequality in the Netherlands. Figure 1 shows how the distribution of pre-tax real hourly wages of employees in the Netherlands changed during the last decade. Wage inequality among full-time working employees increased somewhat (see panel A). However, when we look at part-time working employees, the trend is opposite. The net effect of the trends for full-time and part-time workers is close to zero. The $90 / 10,80 / 20$ and 50/10 percentile ratio of the wage distribution of full-time workers remained unchanged (see panel B), while the 80/20-ratio increased slightly, and the 90/10-ratio increased somewhat more. This implies that the slight change of inequality was due to changes in the wage distribution. 
Figure 1. Trends in wage inequality, 2000-2008

A. Standardized Gini and Theil coefficients

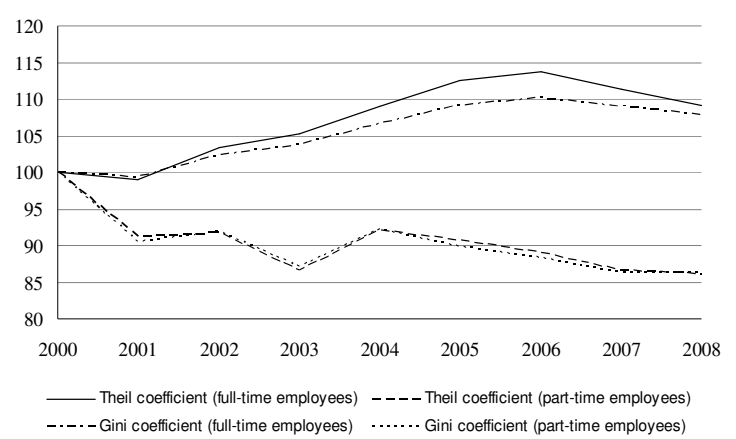

B. Standardized percentile ratios of full-time workers

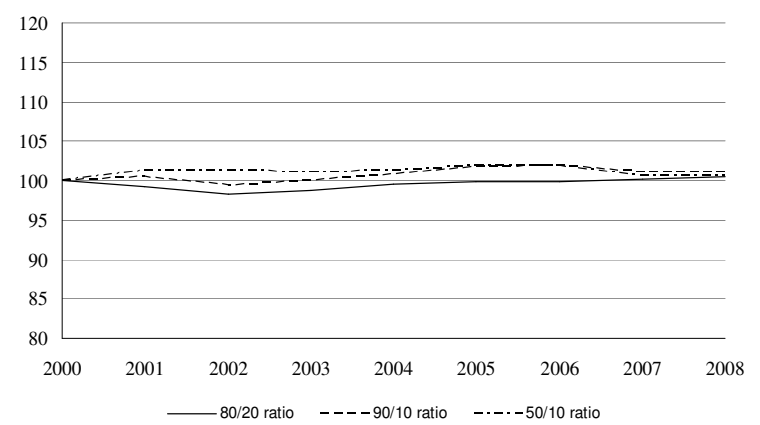

These results are in line with previous studies on wage inequality in the Netherlands (Ter Weel, 2003, Irrgang and Hoeberichts, 2006; Suyker and De Groot, 2006; SCP, 2007, Van den BrakelHofmans, 2007). Comparative research into wage inequality in advanced countries indicates that, during the past two decades, wage inequality increased in most OECD countries (OECD, 2007; Gottschalk and Smeeding, 1997). The Netherlands thus appears to be one of the few exceptions to the general trend. There is some variety in studies that rank countries based on wage inequality, but the Netherlands is generally viewed as a country with a relatively egalitarian distribution and only a slight increase in inequality (see, for instance, Förster and Mira d'Ercole, 2005; Burniaux et al., 2006). ${ }^{4}$ Notwithstanding these results, recent findings of Straathof et al. (2010), indicate that also in the Netherlands top wage inequality has started to increase somewhat, following the international trend.

As the Theil index is an entropy, it is relatively straightforward to decompose inequality into different components (Theil, 1979). Authors like Bourguignon (1979) and Shorrocks (1980) have developed a simple methodology to decompose inequality into a within-group component and a between-group component. Inequality within each subgroup $g$ is given by:

$$
T_{g}=\sum_{i=1}^{l_{g}} \frac{w_{g, i}}{w_{g}} \ln \left(\frac{w_{g, i}}{w_{g}}\right),
$$

\footnotetext{
${ }^{4}$ The OECD (2007) reports the same for disposable income, but reports a clear increase in wage dispersion measured as the $90^{\text {th }}$ to $10^{\text {th }}$ percentile ratio.
} 
where $l_{g}$ is the number of workers in group $g, w_{g, i}$ the wage of each worker and $w_{g}$ the average wage of the workers in the group. Inequality between these subgroups is then given by

$$
T_{\text {between }}=\sum_{g=1}^{N} \frac{l_{g}}{L} \frac{w_{g}}{\bar{w}} \ln \left(\frac{w_{g}}{\bar{w}}\right),
$$

where $N$ equals the number of groups that are defined, $L$ the total labour force, and $\bar{w}$ the average wage across all workers. When inequality within each subgroup has been calculated using equation (1) and between-group inequality using equation (2), total inequality is equal to the sum of average within-group inequality $T_{g}$ in each of the $N$ subgroups that were distinguished (weighted by their economic weight) and between group inequality:

$$
T=\sum_{g=1}^{N} \frac{l_{g}}{L} \frac{w_{g}}{\bar{w}} T_{g}+T_{\text {between }} .
$$

The Theil index thus provides the possibility of an exact decomposition of inequality, where different components are meaningful and can be added by simple mathematical manipulations. A disadvantage of the Theil index - which is equal to the mean product of income and its own logarithm (Theil, 1972, pp. 100) - is that its interpretation has no clear economic logic. The popularity of the Theil coefficient in the economic literature is thus largely based on its suitability for estimating the contribution of different groups to total inequality (Fields, 1979). ${ }^{5}$

The Theil coefficient can also be used to further decompose total between group inequality into the specific contribution of each type of between group inequality (e.g. education, experience, gender and part-time vs. full-time in our case), by a more sophisticated extension of the Theil model that was introduced by Fishlow (1972). The contribution of one type of between group inequality can be written formally as:

$$
T_{\text {between-education }}=\sum_{\text {edu }=1}^{7} \frac{l_{\text {edu }}}{L} \frac{w_{\text {edu }}}{\bar{w}} \ln \left(\frac{w_{\text {edu }}}{\bar{w}}\right)
$$

\footnotetext{
${ }^{5}$ In this respect, the Gini coefficient is the exact opposite of the Theil coefficient. The Gini coefficient is often used for its clear economic interpretation, which originates in the Lorenz curve. Gini decomposition procedures have been developed by, among others, Rao (1969) and Fei and Ranis (1974). These methods are not based on weighting different inequality components, since ranking of subgroups on each of this different inequality is required, but on more complex calculation methods (Fields, 1979).
} 
where the average wage in each industry is:

$$
w_{\text {edu }}=\left[\sum_{\text {edu }=1}^{7} \sum_{\text {age }=1}^{11} \sum_{\text {gen }=1}^{2} \sum_{\text {part }=1}^{2} \frac{l_{\text {edu,age, gen, }, \text { part }, i}}{l_{\text {edu }}} w_{\text {edu, age,gen, part }, i}\right] .
$$

Similar equations yield the contribution of gender and experience to total inequality between groups. Total between-group inequality is given by the sum of the different components, and a remaining part with random effects and interactions. Formally:

$$
T_{\text {between }}=T_{\text {between-education }}+T_{\text {between-experience }}+T_{\text {between-gender }}+T_{\text {between-part-time }}+T_{\text {between-interactions }} .
$$

We use this equation to determine how much of total between-group inequality is explained by variation among industry, gender, and experience wage averages. The difference between equation (2) and equation (6) stems from the exclusion of variation in income classes, and is equal to the within-group variance.

Figure 2. Trends in wage inequality, 2000-2008

Theil coefficients of within and between inequality

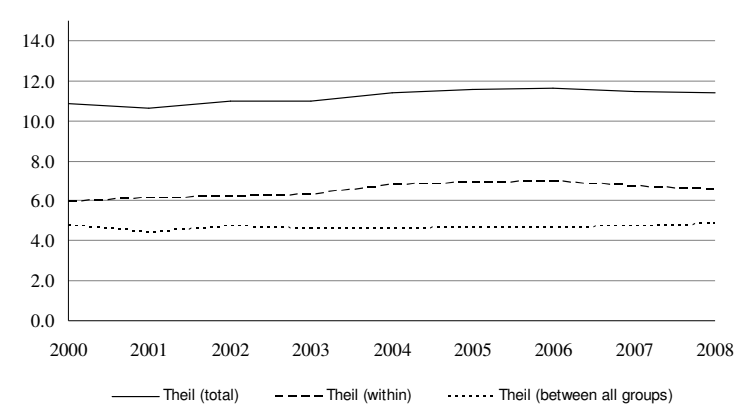

Additional decompositions for 2008

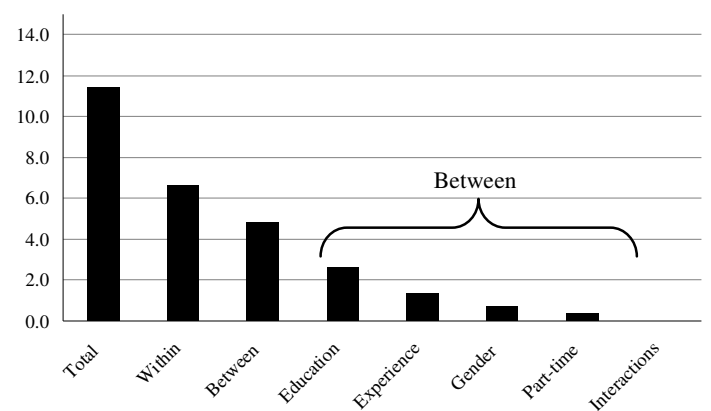

The left panel of Figure 2 shows the development of total, within and between-group inequality, as computed by the method described in equations (1)-(3). It reveals a marginal increase of total wage inequality. About $40 \%$ of inequality is due to between-group differences, and it appears that the share of between-group inequality has remained fairly constant. The right panel of Figure 2 and Table 2 shows the results of a further decomposition of inequality between groups with the method described in equations (4)-(6). The most important source of between-group inequality is 
between workers with different levels of education, followed by differences between workers that differ by age. A relatively small effect is attributed to differences between genders or differences between part-time and full-time workers. Looking at the trends in Table 2, it becomes clear that there is a relatively high variation over time in the different components that sum up to the more constant overall inequality. Inequality between education groups increased by $14 \%$, but this was overcompensated by steep decreases in inequality between workers with different experience levels $(-34 \%)$. The gender gap remained constant, while the amount of inequality associated with differences between part-time and full-time workers has more than doubled.

Table 2. Theil decomposition of pre-tax wage inequality

\begin{tabular}{lrrrrr}
\hline & $\mathbf{2 0 0 0}$ & $\mathbf{2 0 0 2}$ & $\mathbf{2 0 0 4}$ & $\mathbf{2 0 0 6}$ & $\mathbf{2 0 0 8}$ \\
Total & 10.88 & 10.98 & 11.40 & 11.66 & 11.39 \\
Within groups & 5.98 & 6.19 & 6.76 & 6.98 & 6.58 \\
Between groups: & 4.80 & 4.71 & 4.62 & 4.67 & 4.81 \\
Education & 2.31 & 2.51 & 2.44 & 2.52 & 2.63 \\
Experience & 2.03 & 1.62 & 1.40 & 0.71 & 1.32 \\
Gender & 0.72 & 0.64 & 0.21 & 0.26 & 0.72 \\
Part-time & 0.12 & 0.18 & -0.12 & -0.12 & 0.36 \\
Interactions & -0.09 & -0.10 & & & -0.22 \\
\hline
\end{tabular}

As the Gini and Theil indices are aggregate measures for inequality, they are not very informative about where in the wage distribution changes have occurred. An observed change in the coefficients can be consistent with many different underlying processes. Figure 3 shows recent trends in Dutch wage inequality, as measured by percentile changes of log hourly wages between 2000 and 2008, for each percentile of the wage distribution. The median wage has increased by 5.9 percent. The negative slope for the bottom half of the wage distribution implies that wages have become somewhat more equal for the lower incomes. For above median wages, the pattern is diverged, though most of the higher percentiles experienced above median wage growth. At the highest percentiles, there has been some diversion. Workers at the top five percentiles have gained 8.3 percent on average. It seems thus that "the rich" have gained the most, though the difference with the median worker is not large. It is important to note that wages in Figure 1 have not been corrected for a changing composition of the labour market. It could be that the people that are rich in 2008 have different characteristics than those in 2000. 
Figure 3. Trends in wage inequality, 2000-2008

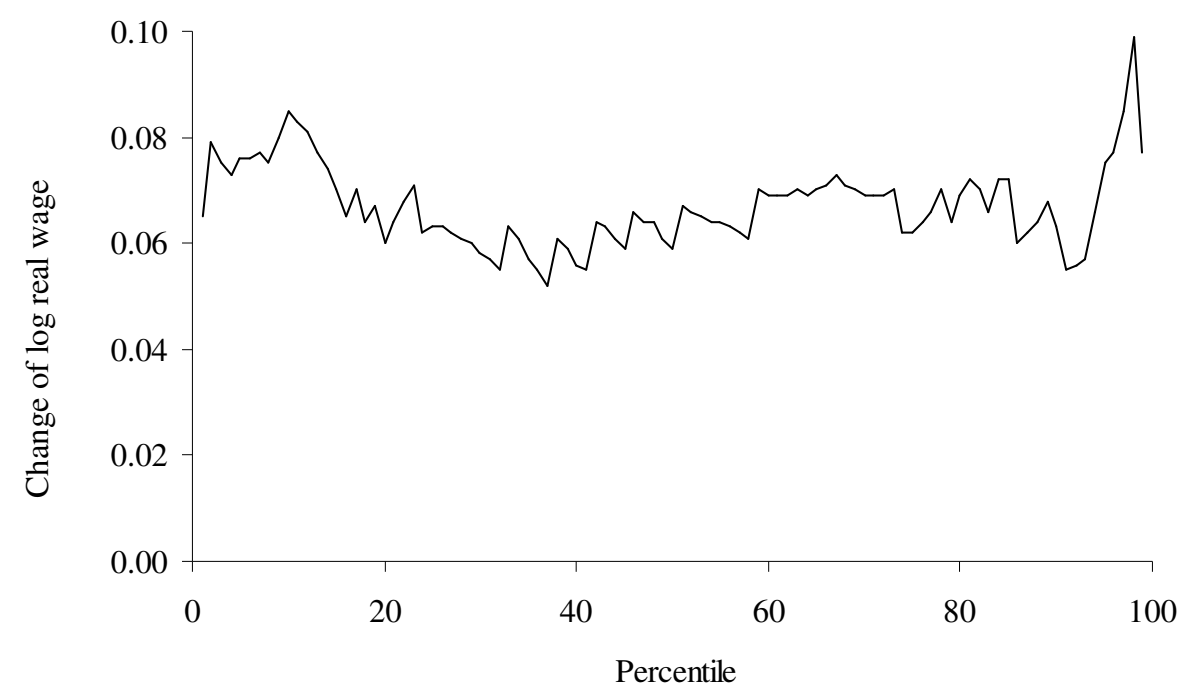

The four panels in Figure 4 compare wage changes by percentiles for different subgroups on the labour market. Differences in average wage growth are related to between group inequality (e.g. if one curve is above another on average, average wage growth was higher in that group), while differences in the shape of the distributions are the result of changing within group inequality. Similar to Figure 3, it compares aggregated change in real log wages between 2000 and 2008. Panel A compares workers with different levels of education. We start by discussing level effects. Wages of workers with only primary education have decreased by 2.0 percent on average in real terms, wages of workers with secondary education increased by 3.5 percent and wages of workers with tertiary education by 4.9 percent. Between group inequality has thus increased (as the highest growth rate was experienced by the group with the highest average wage in 2000), which is consistent with the results of the Theil decomposition. For workers with only primary education, wages around the median and at the highest percentiles have decreased substantially in real terms, while wages at the lower percentiles have remained constant. For workers with secondary education, wages have increased somewhat faster at the lower than at the higher percentiles, thus decreasing within group inequality. Compensation of workers with tertiary

\footnotetext{
${ }^{6}$ This figure is constructed as follows: all employees have been sorted according to their log real wages in both 2000 and 2008. We calculate the change in log real wage at each percentile between 2000 and 2008. Figure 3 gives the relation between the percentile and change in log wage. If wages have increased relatively fast at either the lowest or the highest percentiles (in the centre of the distribution), inequality as defined by common measures like the Theil or Gini indexes would have increased (decreased).
} 
education has increased more at the higher percentiles than at the rest of the distribution, resulting in higher inequality. At first sight, the fact that wages increased by 6.3 percent on average seems incompatible with the finding that wage growth was lower than 6.3 percent at each individual level of education. This is, however, the result of the increased share of higher educated workers. As they are vastly overrepresented in the higher percentiles, this change in labour marked composition results in higher wages at higher percentiles of the aggregate wage distribution, even when inequality within education groups would not have changed at all.

Panel B compares wages of workers of different age. Age groups mainly differ in the level of growth. Wages of workers in their thirties and early forties have increased by 6.8 percent, wages of younger workers by 8.2 percent, and wages of older workers by only 1.2 percent on average. This reduced inequality between groups. The most likely explanation for this phenomenon is a changing skill composition within the group of older workers. Well paid and higher educated workers are far more likely to continue working when they are old than less educated workers, but during the last decade policies targeted at increasing labour market participation of elderly workers have been implemented. As less educated workers are now also more likely to work in their fifties and sixties, the average level of education has decreased. This results in relatively low growth of wages for this group of workers. An alternative explanation is also related to changing institutions. Even though workers are generally thought to reach the top of their productivity between their forties and fifties, older workers have the highest wages for institutional and historical reasons. As the economy has become more competitive, inequality between older workers and workers of middle age could have decreased. Differences between trends in the distribution of wages within the different groups are relatively small. All ages show a similar above average growth of wages at the highest percentiles.

Panel $\mathrm{C}$ shows trends in wages of male and female workers. Wages of males have increased by 7.2 percent on average, wages of females by 8.8 percent. Wages of both genders thus increased faster that the aggregate wage growth of 6.3 percent. This is the result of increased female labour market participation. As wages of females are on average lower than wages of males (male wages were 23 percent higher in 2008), increased labour market participation of women reduces aggregate wage growth. The diversion of wages at the top is much more pronounced for male than for female workers. Also, male wage inequality has increased somewhat across almost the entire distribution, and in particular at the highest percentiles, while 
remaining constant for females. Within group inequality of male workers has thus increased, and between gender inequality was reduced. Panel D compares wages of full-time workers with wages of part-time workers. Wages of full-time workers increased by 9.9 percent, substantially faster than wages of part-time workers, which increased by 4.1 percent. The fact that growth of full-time worker wages outpaced aggregate wage growth is the result of an increased share of part-time jobs. Payment of part-time jobs has become substantially more equal across the entire distribution, which is consistent with a decreasing importance of cohort effects. The increased share of part-time jobs is closely related to increased female labour market participation. Euwals et al. (2007) show that the participation rate of women (at a given age) increases as they are member of younger age cohorts, but find that this effect is now declining. Because of this, an increasing share of the part-time jobs is occupied by older workers (that have higher average wages). This results in a shift in percentiles. 
Figure 4. Trends in wage inequality by subgroup, 2000-2008

A. Change by type of education

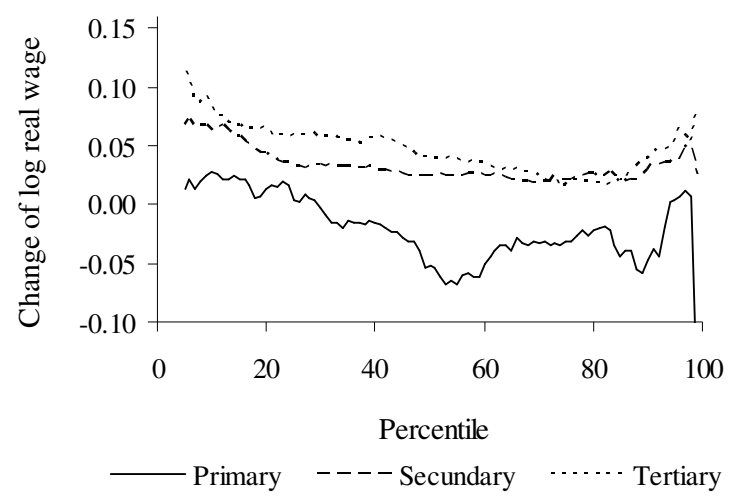

C. Change by gender

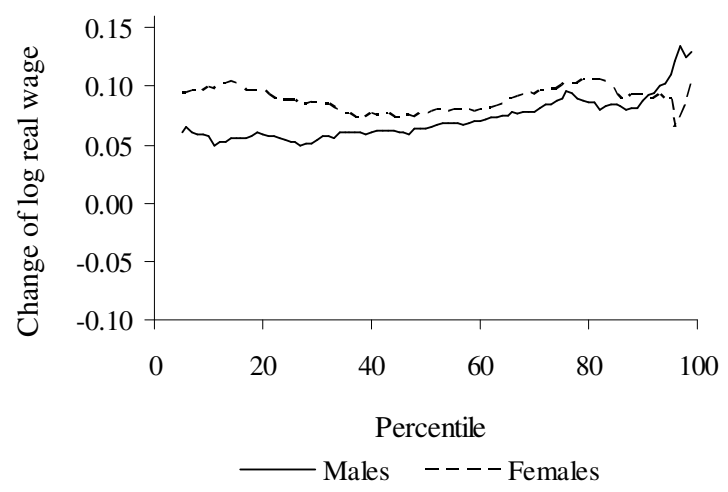

B. Change by age category

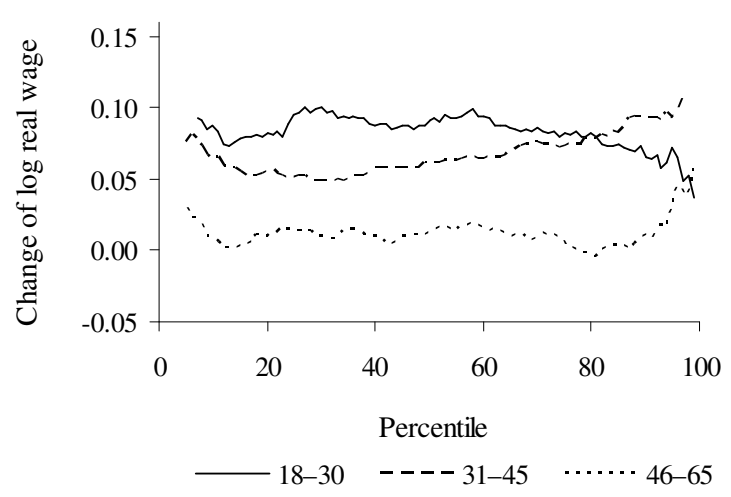

D. Part-time vs. full-time work

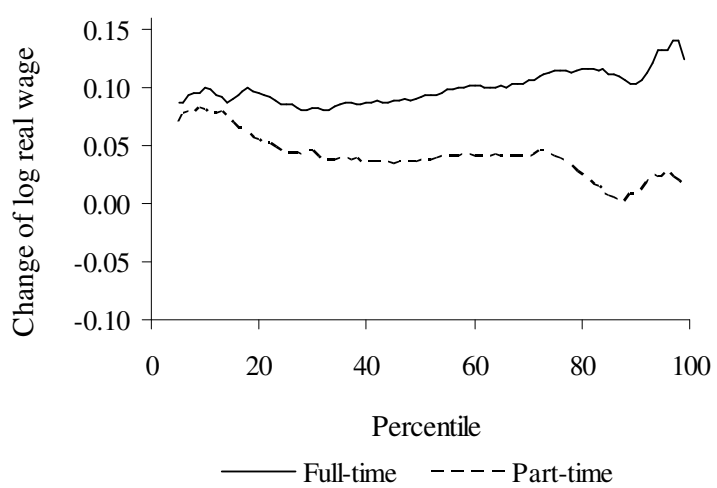

We have thus far seen that composition effects explain a large part of observed trends in the wage structure. The Mincerian wage regression (Mincer, 1974) is an often-used tool to analyze the structure of wages, as it separates variation in wages due to observed worker characteristics from a residual wage component. We have estimated a wage regression for each year separately,

$$
w_{i t}=X_{i t} \beta_{t}+\varepsilon_{i t},
$$

which explains $\log$ wages $w_{i}$ as a function of a constant and worker characteristics $X_{i}$, and a remainder $\varepsilon_{i}$ that is attributed to unobserved differences between workers. We include education (years of educational attainment), age (as a proxy for experience), gender, whether a person 
works part-time or not, and whether a person is a foreign born or not. The results are presented in Table 3. The skill premium (e.g. the monetary value of having attended one additional year of education) ranges from 5.7 percent to 6.4 percent, and is moderately increasing over time. The returns to age or experience are concave, with an estimated top at 55 in 2000 and 52 in 2008 . The career premium, measured as the expected ceteris paribus wage difference between an 18 year old worker and a worker at the career top ranges from 74 percent in 2000 to 70 percent in 2008 . Male workers earn substantially more than females after correcting for other characteristics, fulltime workers more than part-time workers, and native born workers more than foreign born. The latter is most likely at least partially the result of omitted variables, like social skills (for example language).

Table 3. Estimation results wage regressions, 2000-2008

\begin{tabular}{|c|c|c|c|c|c|}
\hline & 2000 & 2002 & 2004 & 2006 & 2008 \\
\hline Education (years) & $\begin{array}{l}0.057 \\
(79.8)\end{array}$ & $\begin{array}{l}0.061 \\
(95.9)\end{array}$ & $\begin{array}{c}0.062 \\
(133.9)\end{array}$ & $\begin{array}{c}0.062 \\
(167.8)\end{array}$ & $\begin{array}{c}0.064 \\
(174.7)\end{array}$ \\
\hline Age & $\begin{array}{l}0.059 \\
(28.4)\end{array}$ & $\begin{array}{l}0.062 \\
(34.6)\end{array}$ & $\begin{array}{l}0.062 \\
(47.1)\end{array}$ & $\begin{array}{l}0.064 \\
(77.6)\end{array}$ & $\begin{array}{l}0.063 \\
(79.2)\end{array}$ \\
\hline Age-squared & $\begin{array}{c}-0.0005 \\
(-21.2)\end{array}$ & $\begin{array}{c}-0.0006 \\
(-27.0)\end{array}$ & $\begin{array}{c}-0.0006 \\
(-37.8)\end{array}$ & $\begin{array}{c}-0.0006 \\
(-63.5)\end{array}$ & $\begin{array}{r}-0.0006 \\
(-64.8)\end{array}$ \\
\hline Female & $\begin{array}{l}-0.177 \\
(-33.2)\end{array}$ & $\begin{array}{l}-0.147 \\
(-31.0)\end{array}$ & $\begin{array}{l}-0.163 \\
(-47.5)\end{array}$ & $\begin{array}{l}-0.197 \\
(-76.3)\end{array}$ & $\begin{array}{l}-0.191 \\
(-73.8)\end{array}$ \\
\hline Part-time & $\begin{array}{c}-0.031 \\
(-5.8)\end{array}$ & $\begin{array}{l}-0.054 \\
(-11.3)\end{array}$ & $\begin{array}{l}-0.051 \\
(-14.9)\end{array}$ & $\begin{array}{c}-0.014 \\
(-5.6)\end{array}$ & $\begin{array}{l}-0.038 \\
(-14.9)\end{array}$ \\
\hline Foreign born & $\begin{array}{c}-0.067 \\
(-8.0)\end{array}$ & $\begin{array}{c}-0.063 \\
(-8.7)\end{array}$ & $\begin{array}{l}-0.070 \\
(-13.1)\end{array}$ & $\begin{array}{l}-0.091 \\
(-20.6)\end{array}$ & $\begin{array}{l}-0.087 \\
(-20.7)\end{array}$ \\
\hline$R^{2}$ & 0.991 & 0.991 & 0.991 & 0.988 & 0.988 \\
\hline
\end{tabular}

Note: t-statistics are between parentheses.

The distribution of the unexplained wage component $\varepsilon_{i}$ can be interpreted as inequality within groups on the labor market with narrowly defined worker characteristics, which is conceptually similar to the within group inequality from the previous section. Sorting all workers in our sample by their residual wage gives the distribution of wages independent from observed human capital. Figure 5 shows trends in residual wage inequality, e.g. the change in residual wage inequality at each percentile between 2000 and 2008. The changes in residual inequality are relatively low, given the fact that our data covers 9 years. Residual wage growth at the top five percentile was 1.5 percent above average. Wages at the lowest percentiles also increased 
somewhat above average. This is in clear contrast with all workers between the $20^{\text {th }}$ and the $80^{\text {th }}$ percentile, where the distribution remained very flat. When we compare Figure 5 with Figure 3, we see that almost all changes in aggregate wages (e.g. before correcting for human capital) are explained by the variables included in the Mincer equation. The resulting residual wage distribution is almost flat. The difference between the highest few percentiles and the rest of the distribution, however, are somewhat more pronounced in Figure 3, providing limited evidence for increasing top wage inequality.

Figure 5. Trends in residual wage inequality, 2000-2008

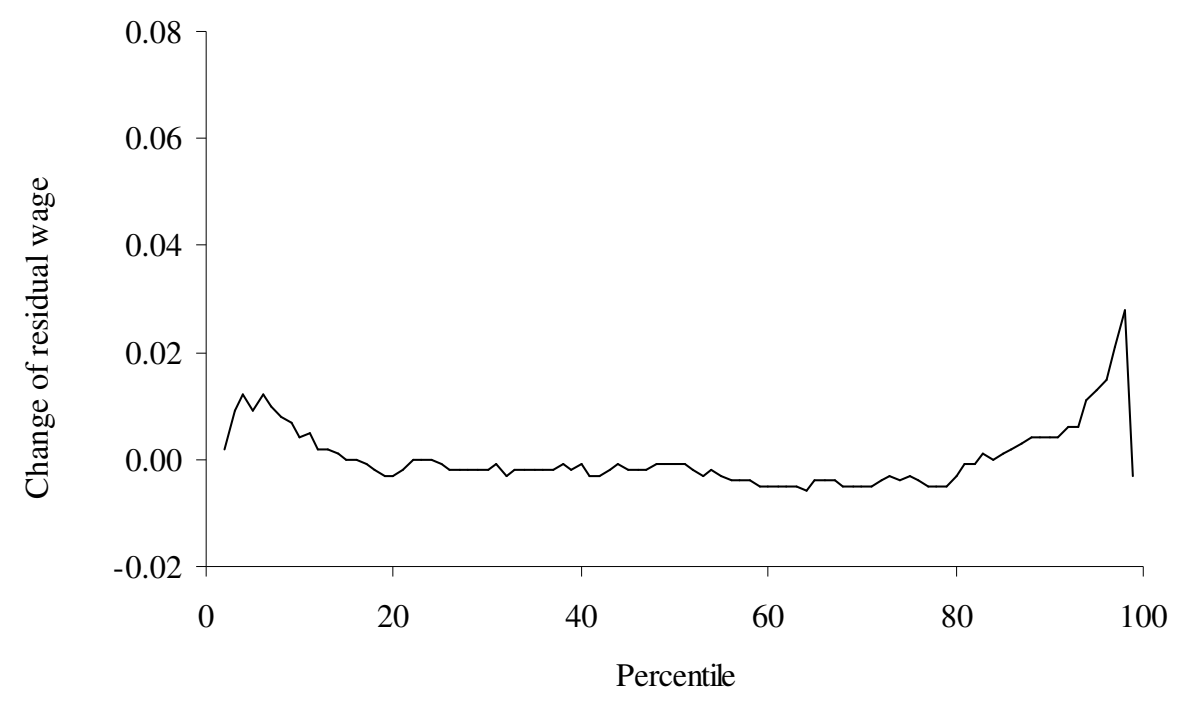

\section{Decomposition of changes in wage inequality}

There are several methods to analyze changes in the structure of wages. Most methods - like the Theil decompositions used in the previous section - typically decompose differences in average wages between groups of workers with certain characteristics (e.g. education, age, gender) in two sets of components: (i) changes in average observed worker characteristics, and (ii) changes in the estimated returns or prices of those characteristics. In this section, we use the technique developed by Juhn et al. (1993) to decompose trends in wage inequality into three components, (i) a part due to quantitative changes of observable worker characteristics - e.g. the number of workers on the labor market with certain characteristics, (ii) a part that can be attributed to price changes - representing the wages that are associated with each of these worker characteristics 
given their supply - and (iii) residual changes that are related to unobservable worker characteristics. The method thus takes residual wage inequality explicitly into account, a feature that other models lack. Another important advantage of the method is that it allows us to analyze the entire wage distribution, instead of just the variance of wages. The method of Juhn et al. is based on estimating wage equations (this is just the Mincer equation, as presented in the previous Section):

$$
w_{i t}=X_{i t} \beta_{t}+u_{i t},
$$

where $w_{i t}$ is a vector with the log hourly wage of individual $i$ in year $t, X_{i t}$ is a matrix with individual characteristics, $\beta_{t}$ is a matrix vector with separate regression coefficients for each year and $u_{i t}$ an error term that captures all unobserved dimensions of the wage. In each year, we sort all workers according to their residual wage. The residual $u_{i t}$ can be separated into two components: the position of the individual in the residual wage distribution (a percentile rank $\theta_{i t}$ ) and the cumulative distribution function of the residual wage $F_{t}(\cdot)$, which gives the relation between the percentile rank and the amount of residual wage inequality, which varies over time. We thus have:

$$
u_{i t}=F_{t}^{-1}\left(\theta_{i t} \mid X_{i t}\right)
$$

where the right-hand side term is the inverse cumulative distribution of the residual wage of workers with the characteristics $X_{i t}$. So we are left with three sources of changing wage inequality: (i) changing distributions of the characteristics of workers that are captured in $X_{i t}$, (ii) changes in the prices of various observed characteristics, the estimated $\beta_{t}$ 's and (iii) changes in the distribution of the residuals $\left(u_{i t}\right)$. Changes in the residual wage distribution are changes in the relation between the percentile rank, and the residual wage. We define $\bar{\beta}$ as the average price of observable characteristics, and $\bar{F}_{t}^{-1}\left(\cdot \mid X_{i t}\right)$ as the average cumulative residual wage distribution (taking the average residual at each percentile over the years 2000-2008). Wage inequality can subsequently be decomposed in its three sources as follows:

$$
w_{i t}=X_{i t} \bar{\beta}+X_{i t}\left(\beta_{t}-\bar{\beta}\right)+\bar{F}_{t}^{-1}\left(\theta_{i t} \mid X_{i t}\right)+\left[F_{t}^{-1}\left(\theta_{i t} \mid X_{i t}\right)-\bar{F}_{t}^{-1}\left(\theta_{i t} \mid X_{i t}\right)\right] .
$$


The first term represents the effect of a changing labor market composition at fixed prices. The second term captures the effects of changing prices of the observables, keeping the quantities of each worker characteristic fixed, and the third and fourth term capture the effects of changes in the residual wage distribution. We can use equation (10) to reconstruct the wage under ceteris paribus conditions. At a given price level of worker characteristics and a given distribution of residual wages, the wage distribution is given by:

$$
w_{i t}^{q}=X_{i t} \bar{\beta}+\bar{F}_{t}^{-1}\left(\theta_{i t} \mid X_{i t}\right) .
$$

If we keep only the residual wage distribution constant, such that both prices and observed characteristics of workers vary over time, the distribution of wages is given by:

$$
w_{i t}^{p, q}=X_{i t} \beta_{t}+\bar{F}_{t}^{-1}\left(\theta_{i t} \mid X_{i t}\right)
$$

If all three sources of wage change vary together, changes in wage inequality are captured by:

$$
w_{i t}^{p, q, d}=X_{i t} \beta_{t}+F_{t}^{-1}\left(\theta_{i t} \mid X_{i t}\right)=X_{i t} \beta_{t}+u_{i t} .
$$

A convenient way to identify these different effects is to start by estimating equation (13), which is equivalent to equation (8). The regression coefficients of different years are used to obtain average prices $\bar{\beta}$. After sorting the residuals (in each year separately) we can determine the average residual over the years in each percentile. The next step is to calculate quantity effects, using equation (11), and price effects, by taking the difference between equations (12) and (11). The effects of changes in the residual wage distribution are given by the difference of equation (13) and (12).

Juhn et al. (1993) use their methodology to decompose changes in wage inequality in price and quantity effects for all worker characteristics together. We now propose a simple extension to their framework, which enables us to isolate effects of different worker characteristics. Let $\mathbf{x}_{i t}^{m}$ be a vector with the quantities of individual worker characteristic $m$ with corresponding price $\beta_{t}^{m}$, and $X_{i t}^{\prime}$ a matrix with all other observed quantities (with prices $\beta_{t}^{\prime}$ ), such that $\mathbf{x}_{i t}^{m} \beta_{t}^{m}+X^{\prime}{ }_{i t} \beta_{t}^{\prime}=X_{i t} \beta_{t} . X^{\prime}{ }_{i t}$ is thus very similar to $X_{i t}$, but it does not include the variable $m$ that we would like to isolate, which is in the vector $\mathbf{x}_{i t}^{m}$. We define $\varphi_{i t}$ to be the 
position of an individual in the conditional wage distribution $F_{t}^{-1}\left(\varphi_{i t} \mid X^{\prime}{ }_{i t} \beta^{\prime}{ }_{t}\right)$, representing the distribution of wages conditional on quantities and prices of all worker characteristics except characteristic $m$. As before, $\beta_{t}^{m}$ and $\beta_{t}^{\prime}$ are estimated using equation (13). By keeping $F_{t}^{-1}\left(\varphi_{i t} \mid X_{i t}^{\prime} \beta_{t}^{\prime}\right)$ constant, we can isolate the effects of changes related to characteristic $m$ from changes in both the residual distribution and changes in the wage distribution related to all other worker characteristics. The ceteris paribus effect of changes in the quantity of $m$ is given by:

$$
w_{i t}^{q}=\mathbf{x}_{i t}^{m} \bar{\beta}_{t}^{m}+\bar{F}_{t}^{-1}\left(\varphi_{i t} \mid X^{\prime}{ }_{i t} \beta_{t}^{\prime}\right)
$$

and the effect of changes in prices and quantities of characteristic $m$ jointly give rise to:

$$
w_{i t}^{p, q}=\mathbf{x}_{i t}^{m} \beta_{t}^{m}+\bar{F}_{t}^{-1}\left(\varphi_{i t} \mid X^{\prime}{ }_{i t} \beta^{\prime}{ }_{t}\right)
$$

A difference between the above equations and equations (11) and (12) is that $\mathbf{x}_{i t}^{m}$ and $\bar{F}_{t}^{-1}\left(\varphi_{i t} \mid X^{\prime}{ }_{i t} \beta^{\prime}{ }_{t}\right)$ are correlated, whereas $X_{i t}$ and $\bar{F}_{t}^{-1}\left(\theta_{i t} \mid X_{i t}\right)$ are independent. Within groups with similar characteristics, however, the distribution of $\bar{F}_{t}^{-1}\left(\varphi_{i t} \mid X_{i t}^{\prime} \beta_{t}^{\prime}\right)$ remains to be uncorrelated from $\mathbf{x}_{i t}^{m}$. This implies that interdependencies between characteristic $m$ and the distribution of wages related to all other worker characteristics (for example the fact that older workers are relatively skill abundant) is captured in $\bar{F}_{t}^{-1}\left(\varphi_{i t} \mid X_{i t}^{\prime} \beta_{t}^{\prime}\right)$, whereas changes in $F_{t}^{-1}\left(\varphi_{i t} \mid X_{i t}^{\prime} \beta_{t}^{\prime}\right)$ that are the result of changes in $\mathbf{x}_{i t}^{m}$ are not captured. This implies that, for example, an increasing share of higher educated workers resulting from a higher participation rate of older workers - that have a higher average level of education - will not be captured. We can thus estimate a wage distribution corresponding to changed prices and quantities of characteristic $m$ as if all other worker characteristics had remained unchanged.

Panel A in Table 4 gives the results of the decompositions for all worker characteristics combined. Changes in the $99-90^{\text {th }}$ differential are partly due to composition effects (observed quantities), but are mostly due to changes in the residual wage distribution. Price effects have slightly reduced inequality at the highest percentiles. This is consistent with the findings of the previous section, which showed a strong increase of residual wage inequality at the highest percentiles. The unchanged $90-50^{\text {th }}$ differential is the net effect of different opposite forces. Observed quantities have reduced inequality, whereas observed prices tended to increase 
inequality. The lower half of the wage distribution shows a different pattern. Here, a changing labor market composition fully explains decreased inequality, although its effect is somewhat moderated by changing prices of human capital. Within group inequality remained unchanged. The panels $\mathrm{B}$ and $\mathrm{C}$ show the isolated effects of education and experience on the wage distribution (recall that all variables on human capital are still included in the regression analysis). The diverged pattern shows that education or experience alone do not provide a clear cut explanation for observed changes in the aggregate wage distribution. Different types of human capital have opposite or interacting effects on the wage distribution.

Table 4. Decomposition of wage inequality, 2000-2008

\begin{tabular}{lcccc}
\hline & $\begin{array}{c}\text { Total } \\
\text { change } \\
\text { Differential }\end{array}$ & $\begin{array}{c}\text { Observed } \\
\text { quantities } \\
(\mathbf{2})\end{array}$ & $\begin{array}{c}\text { Observed } \\
\text { prices } \\
(\mathbf{3})\end{array}$ & $\begin{array}{c}\text { Residual } \\
\text { distribution } \\
(\mathbf{4})\end{array}$ \\
\hline & \multicolumn{5}{c}{ A. All characteristics } \\
$99-90^{\text {th }}$ & 0.013 & 0.007 & -0.006 & 0.011 \\
$90-50^{\text {th }}$ & 0.002 & -0.007 & 0.008 & 0.001 \\
$50-10^{\text {th }}$ & -0.020 & -0.030 & 0.013 & -0.003 \\
& & & & \\
$99-90^{\text {th }}$ & 0.013 & -0.011 & 0.010 & 0.014 \\
$90-50^{\text {th }}$ & 0.002 & -0.022 & 0.012 & 0.011 \\
$50-10^{\text {th }}$ & -0.020 & -0.005 & 0.015 & -0.031 \\
& & C. Only experience & \\
$99-90^{\text {th }}$ & 0.013 & -0.007 & -0.016 & 0.036 \\
$90-50^{\text {th }}$ & 0.002 & -0.003 & -0.009 & 0.014 \\
$50-10^{\text {th }}$ & -0.020 & -0.030 & -0.001 & 0.011 \\
\hline
\end{tabular}

The broad picture of Table 4 nevertheless seems to be consistent with the findings presented in Figure 3. It shows that wage inequality within groups of workers with homogeneous skill characteristics decreased for the lower percentiles (this is consistent with the negative slope in Panel A of Figure 4), whereas within group inequality remained stable for most of the above median workers (which implies a zero slope in Figure 4), and increased at the top few percentiles (positive slope in Figure 4). Wage inequality within groups with similar experience has stayed constant at the lower half of the distribution, and is increasing as we approach the highest percentiles. 


\section{The regional dimension of wage inequality}

Wages do not only vary across workers with different human capital endowments and across occupations, but there are also substantial regional wage differences (see Glaeser et al, 2008, for the United States, and Gibbons et al., 2010, for the United Kingdom). This is to some extent explained by spatial heterogeneity in the distribution of workers and economic activities (and thus different job types), but after correcting for these, there remain regional wage disparities due to differences in the level of productivity that are quite large in some regions. Table 5 shows levels and trends in the distribution of pre-tax wages and residual wages between and within the 22 largest agglomerations (as defined by Statistics Netherlands) and the periphery (which we define as all municipalities outside the agglomerations. Jobs in the largest agglomerations pay a clear premium over the periphery (column 4), even after correction for human capital (see also Groot et al., 2011). Absolute wages in Amsterdam are about 20 percent higher than in the periphery, while the residual wage differential (the average of the residual wage of all workers in a region) is about 10.2 percent. In several other agglomerations there is a negative average spatial residual. A worker with a standardised level of human capital is expected to earn a 7.7 percent lower wage in Enschede than in a peripheral municipality, and 6.1 percent in Heerlen. There is a positive and significant correlation of 0.47 between the level of (residual) wages and (residual) wage growth, pointing at enhanced regional disparities. Agglomeration externalities provide a partial explanation for the observed differences in residual wages across regions (cf. Groot et al., 2011).

When looking at the percentile ratios for different regions presented in the columns 6 to 8 in Table 5, it appears that regional differences in the log wage distribution below the median are relatively small. A potential explanation for this is that institutions - that do not differ between regions - are more important at the bottom of the wage distribution than at the top. Above the median, and especially at the top of the distribution, there are some substantial differences. As expected - given the presence of many high quality jobs - the $90-50^{\text {th }}$ percentile differential is slightly higher in the Randstad agglomerations - in particular in Amsterdam, where the differential is $(0.686)$. The lowest $90-50^{\text {th }}$ percentile differentials are found in agglomerations outside the Randstad. The highest $99-90^{\text {th }}$ percentile differential is found in The Hague $(0.733)$, while it is the lowest in 's-Hertogenbosch (0.474). In general, inequality at the highest percentiles 
is somewhat higher in agglomerations with high average wages. ${ }^{7}$ Furthermore, there is a relation between initial (above median) inequality and trends in inequality. In case of the agglomerations in Table 5, there is a correlation coefficient of 0.48 for the $99-90^{\text {th }}$ differential, 0.48 for the 90 $50^{\text {th }}$ percentile differential and 0.11 for the $50-10^{\text {th }}$ differential. So inequality in already unequal agglomerations increased relatively fast, especially in the highest percentiles.

\footnotetext{
${ }^{7}$ It is to be noted that the relatively low number of observations for individual agglomerations makes the results less reliable. For example in Sittard/Geleen, the smallest agglomeration in Table 5, our dataset contains only 250 observations per year. There are thus only 2 workers above the $99^{\text {th }}$ percentile.
} 


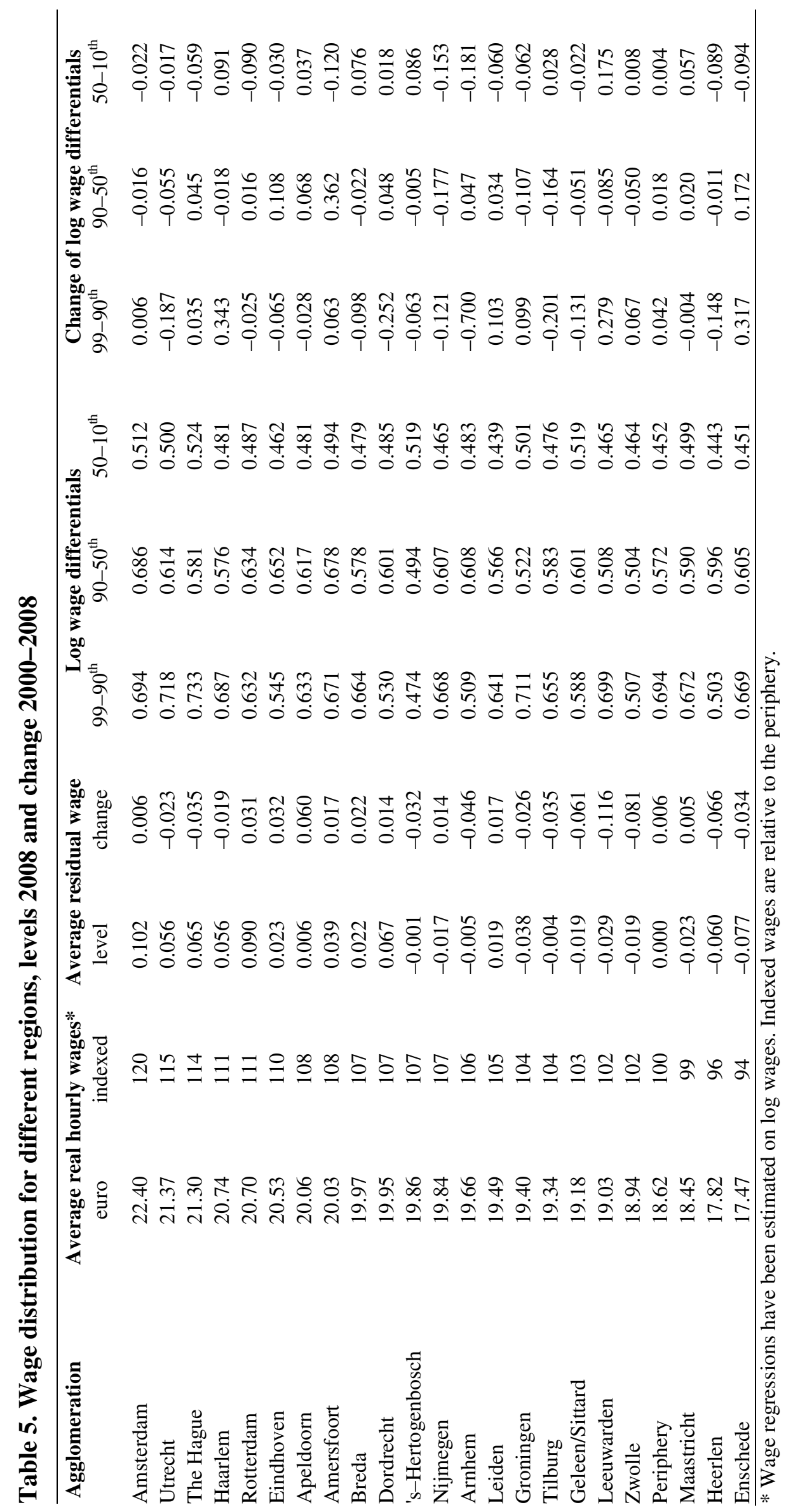




\section{Conclusions}

This paper has examined levels and trends in the Dutch wage structure between 2000 and 2008, using micro data from Statistics Netherlands. It has been shown that (real pre-tax) wage inequality has increased slightly across different dimensions, especially at the top of the wage distribution. These changes are, however, mostly the result of composition effects. Without accounting for changes in the composition of the work force, the $99-10^{\text {th }}$ percentile differential increased by 1.3 percent, the $90-50^{\text {th }}$ differential by 0.2 percent, while the $50-10^{\text {th }}$ ratio decreased by 2.0 percent. When we correct for trends in observed worker characteristics by estimating Mincerian wage equations, changes in residual inequality are respectively 1.1 percent, 0.1 percent and -0.3 percent growth. In addition, we found that wages increased faster in regions with a higher initial wage, especially in the large agglomerations in the Randstad area. This study finds, consistent with previous work, that changes of wage inequality are moderate in the Netherlands, compared to the United States and other advanced economies. It is shown, however, that this is in fact the net effect of counteracting underlying changes. Changes in the composition of the labour market - or observed quantities of worker characteristics in the terminology of Juhn et al. (1993) - have generally resulted in lower inequality. This is, however, the net effect of a changing composition with respect to age, resulting in decreasing inequality, and a changing skill composition resulting in higher inequality. Increasing skill prices are the main explanation for the higher $90-50^{\text {th }}$ percentile ratio, whereas changes in the residual wage distribution provide an explanation for changes in the $99-90^{\text {th }}$ percentile ratio. The findings of the paper are consistent with the empirical implications of both skill biased technological progress as well as globalization (due to similar empirical implications of the two). We do not find evidence for polarization in the Netherlands, in contrast with the findings of Goos and Manning (2007) on the U.K. and Autor et al. (2008) on the U.S. labour market. Further research will be needed to isolate the empirical effects of different potential explanations for observed changes in the structure of the Dutch labour market. 


\section{References}

Alderson, A.S. and F. Nielsen, 2002, Globalization and the great U-turn: Income inequality trends in 16 OECD countries, American Journal of Sociology, 107, pp. 1244-1299.

Atkinson, A.B. and W. Salverda, 2005, Top incomes in the Netherlands and the United Kingdom over the 20th century, Journal of the European Economic Association, 3, pp. 883-913.

Autor, D.H., L.F. Katz and A.B. Krueger, 1998, Computing inequality: have computers changed the labour market?, Quarterly Journal of Economics, 113, pp. 1169-1213.

Autor, D.H., L.F. Katz and M.S. Kearney, 2006, The polarization of the U.S. labour market, NBER Working Paper, no. 11986, Cambridge MA.

Autor, D.H., L.F. Katz and M.S. Kearney, 2008, Trends in U.S. wage inequality: revising the revisionists, Review of Economics and Statistics, 90, pp. 300-323.

Bourguignon, F., 1979, Decomposable income inequality measures, Econometrica, 47, pp. 901920.

Burniaux, J., F. Padrini and N. Brandt, 2006, Labour market performance, income inequality and poverty in OECD countries, OECD Economics Department Working Paper, no. 500, Paris.

Euwals, R., M. Knoef and D. van Vuuren, 2007, The trend in female labour force participation: what can be expected for the future?, CPB Discussion Paper, no. 93, The Hague.

Fei, J.H.C. and G. Ranis, 1974, Income inequality by additive factor components, Economic Growth Center Discussion Paper, no. 267, Yale University, New Haven, CT.

Fields, G.S., 1979, Decomposing LDC inequality, Oxford Economic Papers, 31, pp. 437-459.

Fishlow, A., 1972, Brazilian size distribution of income, American Economic Review, 62, pp. 391-402.

Förster, M and M. Mira d' Ercole, 2005, Income distribution and poverty in OECD countries in the second half of the 1990s, OECD Social, Employment and Migration Papers, no. 22, Paris.

Gibbons, S., H.G. Overman and P. Pelkonen, 2010, Wage disparities in Britain: People of place?, SERC Discussion Paper, no. 60, London. 
Glaeser, E.L., M.G. Resseger and K. Tobio, 2008, Urban inequality, NBER Working Paper, no. 14419, Cambridge, MA.

Goos, M. and A. Manning, 2007, Lousy and lovely jobs: the rising polarization of work in Brittain, Review of Economics and Statistics, 89, pp. 118-139.

Gottschalk, P. and T.M. Smeeding, 1997, Cross-national comparison of earnings and income inequality, Journal of Economic Literature, 35, pp. 633-687.

Groot, S.P.T., H.L.F. de Groot and M.J. Smit, 2011, Regional wage differences in the Netherlands: micro-evidence on agglomeration externalities, TI Discussion Paper, no. 2011050/3, Amsterdam-Rotterdam.

Irrgang, E. and M. Hoeberichts, 2006, Inkomensongelijkheid in de eenentwintigste eeuw, Economisch Statistische Berichten, 91, pp. 152-153.

Juhn, C., K.M. Murphy and B. Pierce, 1993, Wage inequality and the rise in returns to skill, Journal of Political Economy, 101, pp. 410-442.

Katz, L.F. and K.M. Murphy, 1992, Changes in relative wages 1963-1987: supply and demand factors, Quarterly Journal of Economics, 107, pp. 35-78.

Lawrence, R.Z., 2008, Blue-collar blues: is trade to blame for rising US income inequality? Policy Analysis in International Economics no 85, Peterson Institute for International Economics, Washington DC.

Mincer, J., 1974, Schooling, experience, and earnings, New York, NBER.

Nahuis, R. and H.L.F. de Groot, 2003, Rising skill premia: you ain't seen nothing yet, CPB Discussion Paper, no. 20, The Hague.

Oaxaca, R., 1973, Male-Female wage differentials in urban labour markets, International Economic Review, 14, pp. 693-709.

OECD, 2007, Workers in the global economy: increasingly vulnerable? Employment Outlook, Paris.

Rao, V.M., 1969, Two decompositions of concentration ratios, Journal of the Royal Statistical Society, 132, pp. 418-425. 
SCP, 2007, De sociale staat van Nederland, The Hague.

Shorrocks, A.F., 1980, The class of additively decomposable inequality measures, Econometrica, 48, pp. 613-625.

Straathof, S.M., S.P.T. Groot and J.L. Möhlmann, 2010, Hoge bomen in de polder: globalisering en topbeloningen in Nederland, CPB Document, no. 199, The Hague.

Suyker, W.B.C., P. Buitelaar and H.L.F. de Groot (eds), 2007, India and the Dutch economy, CPB Document, no. 155, The Hague.

Ter Weel, B., 2003, The structure of wages in The Netherlands, 1986-1998, Labour, 17, pp. 371-382.

Teulings, C.N. and J. Hartog, 1998, Corporatism or competition? Labour contracts, institutions and wage structures in international comparison, Cambridge, Cambridge University Press.

Theil, H., 1972, Statistical decomposition analysis, Amsterdam, North-Holland Publishing Company.

Theil, H., 1979, The measurement of inequality by components of income, Economics Letters, 2, pp. 197-199.

Van den Brakel-Hofmans, M., 2007, De ongelijkheid van inkomens in Nederland, $C B S$ Sociaaleconomische Trends, 3e kwartaal, pp. 7-11. 
Publisher:

CPB Netherlands Bureau for Economic Policy Analysis

P.O. Box $80510 \mid 2508$ GM The Hague

$\mathrm{T}(070) 3383380$

July 2011 | ISBN 978-90-5833-520-3 